\title{
Implantação do setor de educação do IEB
}

Elly Aparecida Rozo Vaz Perez Ferrari ${ }^{1}$

O Instituto de Estudos Brasileiros inaugurou, em outubro de 2006, o setor Educação IEB responsável pelo desenvolvimento de programas de visitação ao Instituto. $\mathrm{O}$ formato desses programas é totalmente voltado às especificidades dos acervos da instituição que agrega Arquivo, Biblioteca e Coleção de Artes Visuais para o atendimento a grupos organizados e ao público em geral.

Assim, ao oferecer atividades educativas, o Educação IEB objetiva também introduzir outros segmentos da comunidade ao público já freqüentador do Instituto, a fim de garantir a sua efetiva integração na vida universitária.

Para tanto pretende-se:

- atender de forma qualificada, o público que visita as exposições realizadas pelo IEB;

- desenvolver oficinas temáticas, visitas orientadas e atividades educativas relacionadas aos conteúdos e temas explorados pelas diversas exposições;

- desenvolver, em parceria com os demais setores do IEB - e assessorada por seus docentes - projetos de exposições itinerantes que deverão circular pelos diversos campi da Universidade de São Paulo (USP) e por bibliotecas e escolas da rede pública de ensino médio e fundamental;

- desenvolver atividades voltadas para alunos da USP mostrando as várias possibilidades de pesquisa e profissionalização relacionadas aos acervos existentes;

- articular ações e projetos com outras áreas educativas de museus e órgãos da USP consolidando um padrão de excelência e inovação;

- aprofundar o programa A4, que consiste na reflexão sobre a importância da pesquisa e dos acervos sob a guarda do IEB para transformá-los em tema do cotidiano e ampliar o comprometimento institucional.

1 Educadora do IEB com graduação (Centro Universitário Belas Artes - Febasp) e mestrado (Escola de Comunicações e Artes da USP) em artes plásticas, cursando, atualmente doutorado na Faculdade de Educação da USP. Possui especializações em Didática do Ensino Superior (Universidade Federal Rural do Rio de Janeiro - UFRRJ) e Organização de Arquivos (IEB-USP).

E-mail: elly@usp.br. 


\section{Plano de implantação de atividades educativas}

As atividades educativas são desenvolvidas por programas que estão vinculados aos acervos e suas diversas tipologias, ou seja: arquivo-educação para a documentação textual, iconográfica e áudio-visual; arte-educação para a coleção de artes visuais; e educação, no sentido amplo, para as áreas de concentração temática tais como biblioteca, geografia, literatura, música, museologia e outras.

Estes programas comporão os cadernos de educação, isto é, um material impresso para fundamentação das áreas de atuação dos titulares dos fundos, que compõem o conjunto de acervos do IEB, propiciando a compreensão das atividades do titular como um universo a ser relacionado com a área de atuação, de criação e de contexto.

Em termos educacionais, o trabalho se apresenta como uma construção transversal do conhecimento complexo, não se pautando pela lógica linear e cronológica dos conteúdos. Trata-se de atividades relacionais de atualização dos conteúdos da cultura material e imaterial a partir do referencial do visitante.

\section{Programas educativos já desenvolvidos}

\section{Oficinas temáticas}

Modalidade voltada para atividades que tratem de assuntos e conteúdos de cada uma das áreas do Instituto - ou seja, Arquivo, Biblioteca e Coleção de Artes Visuais - com a preocupação básica de inter-relacionar esses conteúdos. Podem tratar de temas dos mais amplos aos mais técnicos, sempre para entendimento do contexto de determinado acervo pessoal ou coleção.

\section{Macunaíma, para crianças}

Voltada para o público infantil (de 6 a 10 anos), esta atividade compõe-se de leitura de uma da muitas aventuras de Macunaíma, apontando as diferenças entre o conceito corrente de herói veiculado pelas diversas mídias, como história em quadrinhos, mangás, desenhos animados e filmes, e o proposto por Mário de Andrade, considerando sua linguagem e suas características de composição. Trabalha-se ainda o vocabulário dando ênfase às questões regionais expostas.

A princípio, foi uma atividade de férias, que passou a ser atividade oferecida regularmente. 


\section{Macunaima, para todos}

Oficina dirigida para educadores e interessados, na qual são exploradas possibilidades pedagógicas do trabalho direto com o texto de Mário de Andrade e outras linguagens artísticas, a partir do referencial das pessoas envolvidas na atividade.

A jornada de um herói sem caráter (2008)

Atividade desenvolvida pelos estagiários Raphael Yanes e William Raphael do Programa de finais de semana nos museus e acervos da USP.

\section{Oficinas ligadas às exposições de longa duração}

Exposição: A arte moderna pelo olhar de Mário de Andrade

Oficina: A paisagem pelo olhar do geógrafo e do escritor

Oficina elaborada para a Semana de Ciência e Tecnologia de 2007, tratando das questões de observação da natureza, sua conceituação e seus respectivos recortes nas artes (e suas linguagens) e na ciência.

Exposição: A arte moderna pelo olhar de Mário de Andrade

Oficina: Paisagem na parede - como pode algo tão parado mudar?

Atividade de intervenção fotográfica a partir de obras expostas. Trabalha-se a mudança do ponto perspecto em relação ao observador da obra

Exposição: Obras raras em acervos públicos

Oficina: Escrevendo com formas

Atividade de análise literária e produção gráfica da obra La fin du monde filmée par l'Ange N. D., de Blaise Cendrars e Fernand Léger.

\section{Oficinas ligadas às exposições de curta duração itinerantes}

Exposição: Osman Lins: vida e obra

Oficina: Osman Lins e o cuidado com a palavra

Atividade literária criada para divulgação do acervo de Osman Lins no XI Congresso Internacional da Abralic - Associação Brasileira de Literatura Comparada. Esta oficina realizou-se em julho de 2008 na USP. Além da exposição de painéis sobre a vida e obra do escritor, houve a leitura comentada do conto $O$ vitral pela pesquisadora Elisabete Ribas, mestranda em Letras na Faculdade de Filosofia, Letras e Ciências Humanas da USP. 
O programa A4 nasceu da observação dos espaços de circulação (externos aos espaços expositivos) e sua relação com as informações que ali são afixadas.

A parede, a coluna, o chão são o veículo para a criação de um hiato de escape de pensamentos, de percepção e estranhamento. Aditar voz à dimensão vertical da exposição e do prédio como um todo, com perguntas ou frase instigantes, proporciona àquele que passa intervenções, adendos ou subtraendos.

Na primeira etapa fizemos duas intervenções no espaço expositivo: Paisagem em transformação - o olhar modernista nas artes plásticas e Os suportes da escrita. Agora estamos em processo de elaboração de mais duas intervenções já se estendendo para outros espaços que não só expositivo: As licocós do Mário e A baleia e o criador.

\section{Programas contínuos}

Finalmente, temos um programa voltado especialmente ao educadores em geografia: Ensinando geografia no IEB, que visa trabalhar pedagogicamente os acervos dos geógrafos como fonte de pesquisa e ensino. Este programa é feito em parceria com Prof $^{\mathrm{a}} \mathrm{Dr}^{\mathrm{a}}$ Vanderli Custório. 